\title{
Which country does it come from? A review of Business-to-Business Purchase Decision Making Process
}

\author{
Dhyah Harjanti $^{1^{*}}$, Jeremia Novianto ${ }^{1}$, and Noneng Rokayah Sukatmadiredja ${ }^{2}$ \\ ${ }^{1}$ Business Management Program, Faculty of Business and Economics, Petra Christian University, \\ J1. Siwalankerto 121-131, Surabaya 60236 Indonesia. \\ ${ }^{2}$ Faculty of Business and Economics, University Pendidikan Sutan Idris, Tanjong Malim, \\ Perak Darul Ridzuan 35900, Malaysia
}

\begin{abstract}
Previous researches show that the country of origin's image of Chinese products tends to be negative. However, the data shows that business-to-business (B2B) purchases of Chinese products in Indonesia are higher than purchases of products from other countries that are considered to have a better reputation. This research aims to study how the country of origin's image plays a role in B2B purchase decision-making process of Chinese products. This research was conducted on B2B consumers who had bought production machines from China. The data obtained in this study are data from two companies of different sizes to be able to see differences and similarities in what factors concern purchases of Chinese production machines. Data is taken from the owners and managers of the two companies involved in the B2B purchasing decision making process. The two companies have also been buying and using Chinese production machines for more than one year so that they can provide information about product advantages and disadvantages. The results showed that the country of origin image was not a significant consideration in the B2B purchasing decision making process. The main factor to be considered is the ability of suppliers to provide products and services according to company needs
\end{abstract}

Keywords: Chinese products, consumer decisions, country of origin's image.

\section{Introduction}

International trade requires each country to produce products that will generate a competitive advantage compared to other countries' products. While products that cannot be efficiently and effectively domestically produced can be obtained by importing from other countries. This condition is also experienced by Indonesia, which imports many products from abroad.

In the process of choosing imported products to buy, consumers are often influenced by the country of origin's image. The country of origin's image (COOI) is perceived as an indicator of overall product quality to reduce the complexity of purchasing decisions $[1,2]$.

* Corresponding author: dhyah@peter.petra.ac.id 
Even though there is extensive research on the role of country of origin's image in the buying process [3-5], most of these studies are carried out in business to consumers (B2C) context. This research aims to study the role of country of origin's image in the purchasing process of production machines originating from China in the business to business (B2B) context.

Production machines are usually imported from developed countries that have a high level of technology, such as Germany, Japan, and Taiwan. Consumer perceptions about the quality of production machines are generally influenced by the country of origin of these machines. For example, there is an assumption that German production machinery has excellent product quality, even the best compared to other countries. The price offered for German production machines is far more expensive than the production machines of other countries which also sell similar products. Meanwhile, the production machines from China, which are relatively much cheaper, are considered to have lower-quality compared to products from Germany, Japan, and Taiwan.

The process of purchasing decision making in the context of business to business (B2B) is traditionally influenced by a rational selection process that is described economically and statistically [6]. Decision making is largely influenced by profit, usually done by searching and gathering information in the decision making process. According to Pandey and Mookerjee, the buying process in organizations is very complicated because it involves many people in an organization who play various roles in purchasing decisions [6]. With so many people involved in the purchase decision-making process, it would take a long time because they have to go through various stages before the final decision is taken.

Even though "made in China" products can be easily found all over the world, consumers still disparaging the quality of those products [5, 7]. This study aims to determine how China's country of origin's image plays a role in the B2B purchase decision making the process of Chinese production machines in Surabaya, East Java, Indonesia. In this study, it is interesting to learn that there are quite some companies who chose to buy and use production machines from China rather than products from other countries. Users of Chinese production machines in Indonesia are quite diverse, ranging from small workshops to large manufacturing companies. Can the B2B purchase decision-making process encourage consumers to choose Chinese products over other countries' products? According to Osmonbekov and Johnston, the purchasing situation has many variations, both the novelty in an organization and the complexity of decision making, up to the level of importance of the purchase for an organization [8].

In the B2B purchasing decision-making process, four factors drive corporate purchases, namely environmental, organizational, interpersonal, and individual. The most extensive factors are environmental factors that include things such as the country's economy, availability of raw materials, technology, politics or regulations, competition in the environment, culture and also customs in the environment of the company the country stands. Environmental factors themselves will also affect organizational factors, such as goals, strategies, structures, systems, and procedures set for the company adjusted to the seven elements on environmental factors. Since the company consists of many individuals, the organizational factor will influence interpersonal factors, such as the influence of expertise and authority of members of a company. This is because each member of the company has a different level of expertise and authority. Interpersonal factors will then affect the individual. This is because the decision-maker is usually only one person. Individual factors themselves have six elements, namely age or level of education, position, motives, nature, preferences, and also the style of purchase. All of these factors will influence decision making in the company.

Decision making in a company is divided into eight processes. The eight processes are carried out before making a business-to-business purchase within the company and must be 
carried out sequentially. The first process is to determine what problems exist in the company if problems have been found within the company, the second process is carried out is to describe what goods or services are needed to resolve the problem. After the goods or services are described, the third process is the company must know the specifications of the goods or services to ensure whether the goods or services can solve the problems of the company.

The three processes above are processes to determine the problem and the goods and services needed by the company. After the company knows its needs, the company will proceed to the fourth process, which is looking for suppliers that can meet the needs of the company. The number of vendors around the company is certainly not small, therefore the fifth process is that the vendor submits a proposal to the company which is then chosen by the company to ensure which vendor is suitable to become the company's supplier. After the specified vendors provide proposals to the company, the sixth process is carried out, namely the selection of suppliers that are considered the most appropriate to meet the needs of the company. For example, the selected vendor can meet the company's demand faster than other vendors.

After the six processes are carried out until a supplier is found for the company, the company will make repeat purchases at the supplier, so the seventh process is the company determines the purchase, records all the company's needs, and when the time needed by the company to get the goods or services until the transaction finally happened. With the end of the buying and selling process of the two parties, a performance review is conducted, the eighth process aimed at assessing the performance of the supplier. This is done to find out whether the supplier can provide the needs of the company in terms of price, timeliness, and ease of transaction.

\subsection{Research Framework}

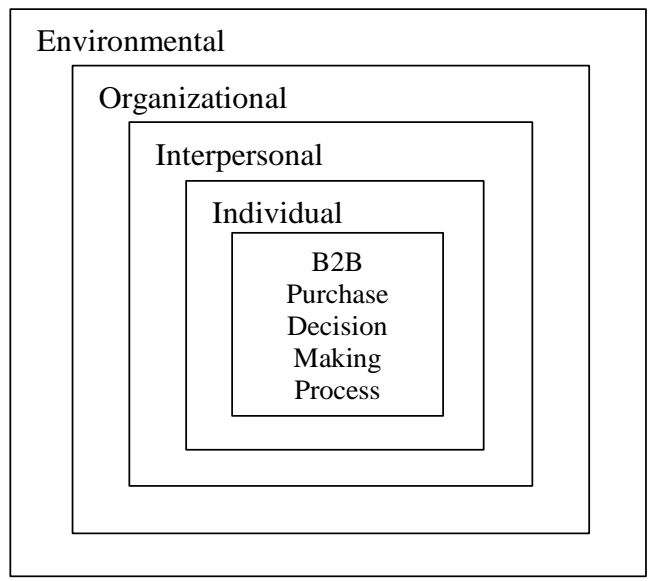

Fig. 1. Research framework

\section{Research method}

This study used descriptive qualitative method. By using qualitative research, researchers can directly describe how the decision making process of purchasing Chinese production machines, as well as knowing how the country of origin's image influences the decisionmaking process. 
In this study, the sample is determined based on a theoretical sampling technique. The companies studied were two companies that had bought and used Chinese products such as lathe, milling, and band saw machines for more than two years. The two companies were chosen to represent differences in company size, number of employees, and target market.

In this study, five informants were obtained consisting of two different company owners and three employees who were head of the factory and head of the purchasing division. The five informants were chosen because they were directly involved in the buying process and also the operation of Chinese production machines. Thus the informant is considered to have been familiar with all the features, specifications, deficiencies, and services provided by the product to be able to explain how the process of purchasing from the company and what are the considerations in the process of purchasing Chinese products.

Data collection techniques used were interviews. Interviews are conducted semistructured, where researchers will prepare several vital questions to guide the course of the question and answer process [9].

Analysis of the data used is interactive data analysis referring to the concept of [10], which consists of data reduction, data presentation, and drawing conclusions and tests. At the data reduction stage, data testing is carried out concerning aspects or focus of the study. Through this process, the researcher can ascertain which data is relevant, related, and not appropriate or not related to the research conducted. The second stage is the presentation of data, where the data are displayed clearly in the form of images, graphs, charts, tables, and the like with the aim that the analyzed data is involved in a single unit. The last step is drawing and testing conclusions. This stage is carried out by conducting a final analysis aimed at confirming which can sharpen the data and clarify understanding.

\section{Analysis}

From the description of the interview result and observation, the two company sources have done a B2B buying process [11]. However, there are similarities and differences to summarize in Table 1 and Table 2 as follow:

Table 1. The similarities of B2B purchasing decision making process and factor of company A and B

\begin{tabular}{ll}
\hline Concepts & Company A and B \\
\hline B2B Buying Process & \\
\hline $\begin{array}{l}\text { A1. Problem } \\
\text { recognition }\end{array}$ & $\begin{array}{l}\text { Both companies recognize a problem before purchasing; in this case, both } \\
\text { companies want to increase productivity by making a new product that } \\
\text { needs a new machine. }\end{array}$ \\
\hline $\begin{array}{l}\text { A2. General need } \\
\text { description }\end{array}$ & $\begin{array}{l}\text { Both companies describe the company's needs directly from the owner. } \\
\text { This is because the buying decision is on A1 and B1. }\end{array}$ \\
\hline $\begin{array}{l}\text { A3. Product } \\
\text { specification }\end{array}$ & $\begin{array}{l}\text { Both companies know the details of the product that is going to be } \\
\text { purchased. A1 realizes and calculates the power from the machine that is } \\
\text { insufficient. On the other hand, B1 knows that most of the machines made } \\
\text { in China are quite decent. }\end{array}$ \\
\hline A4. Supplier search & $\begin{array}{l}\text { Both companies look for a supplier which provides product and service as } \\
\text { needed by them. }\end{array}$ \\
\hline $\begin{array}{l}\text { A7. Order-routine } \\
\text { specification }\end{array}$ & $\begin{array}{l}\text { Both companies give a general rule for a supplier, such as shipping } \\
\text { duration and aftersales service. }\end{array}$ \\
\hline $\begin{array}{l}\text { A8. Performance } \\
\text { review }\end{array}$ & $\begin{array}{l}\text { Both companies evaluate the performance, product, and service of the } \\
\text { supplier. }\end{array}$ \\
\hline B2B Buying Factor & $\begin{array}{l}\text { For environmental factors, both companies agree that the country's } \\
\text { economy, resources, technology, regulations, competition, and customs } \\
\text { influence the buying decisions. For the cultural factor, it does not influence } \\
\text { buying decisions. }\end{array}$ \\
\hline B1. Environmental
\end{tabular}

Table 1. continue to the next page 
Table 1. Continue

\begin{tabular}{ll}
\hline Concepts & Company A and B \\
\hline B2. Organizational & $\begin{array}{l}\text { On organizational factors, both companies agree that the purpose and } \\
\text { strategy influence the company's buying decision. However, for the } \\
\text { structure, system, and procedure, they do not influence the decision. }\end{array}$ \\
\hline B3. Interpersonal & $\begin{array}{l}\text { Both companies agree that the expertise of individuals influences the } \\
\text { buying decision. This is because the buying decision is made directly by } \\
\text { the owner. }\end{array}$ \\
\hline B4. Individual & $\begin{array}{l}\text { In individual factors, age, education level, and position do not influence } \\
\text { according to A1 and B1. Because A1 and B1 ask for suggestions from the } \\
\text { members although they are younger, lower education level or lower } \\
\text { position. In motive, both companies agree that it influences the buying } \\
\text { decision. In buying style, they agree it does not have influence. In } \\
\text { preference, both agree with preference influences the decision, although } \\
\text { both companies have different preferences. }\end{array}$ \\
\hline
\end{tabular}

Table 2. The difference between B2B purchasing decision making process and factor between company A and B

\begin{tabular}{|c|c|c|}
\hline Concept & Company A & Company B \\
\hline \multicolumn{3}{|c|}{ B2B Buying Process } \\
\hline $\begin{array}{l}\text { A4. Supplier } \\
\text { search }\end{array}$ & $\begin{array}{l}\text { Company A concerns the } \\
\text { competitive price from the } \\
\text { supplier. }\end{array}$ & Company B chooses a reliable supplier. \\
\hline $\begin{array}{l}\text { A5. Proposal } \\
\text { solicitation }\end{array}$ & $\begin{array}{l}\text { Company A does not use a } \\
\text { proposal and relies on the price } \\
\text { offered by the supplier. }\end{array}$ & $\begin{array}{l}\text { Company B requires the suppliers to file } \\
\text { a proposal for a comparison. }\end{array}$ \\
\hline Concept & Company A & Company B \\
\hline $\begin{array}{l}\text { A8.Performance } \\
\text { review }\end{array}$ & $\begin{array}{l}\text { A1 does their performance } \\
\text { review }\end{array}$ & $\begin{array}{l}\text { B1 is helped by the technician to review } \\
\text { the performance of the production } \\
\text { machine. While for the supplier } \\
\text { performance review, the purchasing } \\
\text { division helps B1 to review the } \\
\text { performance. }\end{array}$ \\
\hline Concept & Company A & Company B \\
\hline \multicolumn{3}{|c|}{ B2B Buying Factors } \\
\hline $\begin{array}{l}\text { B4. Individual } \\
\text { Character }\end{array}$ & $\begin{array}{l}\text { Company A says that character } \\
\text { traits do not influence in the } \\
\text { buying process, because the } \\
\text { character should not influence a } \\
\text { professional. }\end{array}$ & $\begin{array}{l}\text { Company B says that character traits } \\
\text { influence the buying process, such as if a } \\
\text { person can communicate well, yes, he/she } \\
\text { can influence the buying process. }\end{array}$ \\
\hline $\begin{array}{l}\text { B4. Individual } \\
\text { Preference }\end{array}$ & $\begin{array}{l}\text { Company } \mathrm{A} \text { is looking for an } \\
\text { affordable machine and able to } \\
\text { be used, so the Chinese products } \\
\text { suits the company's preference. }\end{array}$ & $\begin{array}{l}\text { Company B looks for a supplier that has } \\
\text { been established in Indonesia, so it gives } \\
\text { excellent aftersales service. As a result, } \\
\text { B1 trusts the long-established supplier in } \\
\text { Indonesia rather than COOI from a } \\
\text { company. }\end{array}$ \\
\hline
\end{tabular}

Table 2 and Table 3 show that they have more similarities than differences. This is because the B2B buying process and factors influencing the buying decision from both companies align with Kotler and Armstrong [11]. The differences they have are just at preferences.

In the buying process, the more prominent company has a more complicated process. Product specification B1 for company B is helped by the engineering team when determining the needed product to solve their problem. This procedure is doing although they know what products they need. Different from company A, A1 determines the needed product on its own, although it still receives suggestions from other company members if 
some machine trouble occurs. As a matter of fact, in supplier search, proposal solicitation, to supplier selection, they have differences, which A1 directly takes a decision, considers the price, and needs no proposal because the owner directly does the buying process. On the other hand, company B needs proposals from the suppliers, and in the buying process, B1 is helped by the purchasing division to provide data about the supplier, although eventually, B1 takes the decision.

On B2B buying factors for both companies, especially on the individual factor, preference is the most influential factor. This is because the companies have various needs, so the purchase is adjusted to their needs. Company A considers the available low price machine, while company B needs a supplier that gives excellent aftersales service at a reasonable price. Company $\mathrm{B}$ needs the service if the machine has some troubles in the future. Therefore, it can be said that the country of origin's image of China's product influences the price because its price is relatively lower.

On the interpersonal factor, the expertise is influential. The companies, both A and B, agree that the expertise in sales or the members of the company influences the owners to listen to their suggestions to do the buying process. Besides, for organizational factors, the company's strategy gives the most influence for both companies. This is because the strategy determines the product criteria as needed by them.

On the environmental factor, the most influential factor is the country's economy and customs. Both companies agree that if the country's economy is worse, the companies are not able to afford to buy with higher prices, especially when the market demand is low. The companies also learn that Indonesian customs are a bit complicated and it needs more money and time to buy the product. Besides, B1 chooses an excellent aftersales service, and if the product is from abroad directly, it will be challenging to get the aftersales services.

\section{Conclusion}

B2B factors influence eight $\mathrm{B} 2 \mathrm{~B}$ purchasing decision-making processes in a company. B2B buying factors that directly influence the buying process are the individual factor. The individual factor that is the most influential is the preference. At the same time, the element of the country of origin's image of China is not an essential element for the decision-maker of the company. Chinese products have not gained any trust from consumers yet, and this research, both companies $\mathrm{A}$ and $\mathrm{B}$ neglect the COOI of China that often viewed as unfavorable. They emphasize on the price and after sales service given by the supplier.

The interpersonal factor also influences the individual factor through the member of a company and salesperson who offers the product. Both the companies agree that the expertise of a person is the most important thing because if the person masters and understands the product, A1 and B1, as the decision-maker, trusts that person, whether it is the salesperson or the member of the company. The organizational factor is influenced by the interpersonal factor, in which both companies have similarities that the most crucial strategy is the environmental factor. It is because the purchase is adjusted to the strategy set by the company. If the supplier knows the strategy, they know what product needed by the company. In the environmental factor, it is the most comprehensive factor. In this research, the country's economy and customs give the strongest influence. It is because if the country's economy is worse, both of the companies will not purchase the machine. For the customs element, the companies are not willing to import the machine on their own because they will spend more on time and money. Besides, the aftersales service is also challenging to get. 


\section{References}

1. N. Souiden, F. Pons, M.E. Mayrand, Journal of Product \& Brand Management, 20,5:356-367(2011).

https://www.emeraldinsight.com/doi/abs/10.1108/10610421111157883

2. S. Murtiasih, S. Sucherly, H. Siringoringo, Marketing Intelligence \& Planning, 32, 5:616-629(2013). https://www.emeraldinsight.com/doi/abs/10.1108/MIP-04-2013$\underline{0073}$

3. M. Fetscherin, M. Toncar, International Marketing Review, 27,2:164-178(2010). https://www.emeraldinsight.com/doi/abs/10.1108/02651331021037494

4. M.F. Herz, A. Diamantopoulos, Journal of International Marketing, 21,3:95121(2013). https://journals.sagepub.com/doi/abs/10.1509/jim.13.0004

5. NSNM. Yunus, WEW. Rashid, Procedia Economics and Finance, 37:343-349(2016). https://www.sciencedirect.com/science/article/pii/S2212567116301356

6. S.K. Pandey, A. Mookerjee, Journal of Indian Business Research, 10,2:170-192(2017). https://www.emeraldinsight.com/doi/abs/10.1108/JIBR-10-2017-0171

7. S. Lew, Z. Sulaiman, Procedia-Social Behavioral Sciences, 130:37-45(2014). https://www.sciencedirect.com/science/article/pii/S1877042814029152

8. T. Osmonbekov, J.W. Johnston, Journal of Business \& Industrial Marketing, 33:6, 781-791(2018). https://www.emeraldinsight.com/doi/abs/10.1108/JBIM-10-2015-0190

9. U. Sekaran, R. Bougie, Research Method for Business. United Kingdom: John Wiley \& Sons Ltd, (2016). https://books.google.co.id/books?id=Ko6bCgAAQBAJ\&dq

10. M.B. Miles, A.M. Huberman, Qualitative Data Analysis: An Expanded Sourcebook, USA: Sage Publication. (1994). https://vivauniversity.files.wordpress.com/2013/11/milesandhuberman1994.pdf

11. P. Kotler, G. Armstrong, Principles of Marketing. England: Pearson Education Limited (2016). https://www.google.com/books?hl=id\&lr=\&id=UKyaBQAAQBAJ 